\title{
KSIĘGA IZAJASZA Z QUMRAN
}

W roku bieżącym upływa dziesięć lat od chwili, w której jeden $z$ beduinów plemienia Taamire natknął się przypadkowo, w jednej $z$ grot na północno-zachodnich brzegach Morza Martwego na gliniane dzbany zawierające skórzane zwoje pokryte pismem hebrajskim i aramajskim. Grotę tę nazwano obecnie pierwszą, ponieważ jeszcze w dziesięciu innych grotach leżących w pobliżu Chirbet Qumran znaleziono przypadkowo, czy też $w$ rezultacie systematycznych poszukiwań naukowych nowe rękopisy i nowe fragmenty. ${ }^{1}$ ) $\mathrm{Z}$ grot tych pochodzi większość dokumentów. Inne zaś pochodzą z grot północnego zbocza Wadi Murabba'at, odległego o $18 \mathrm{~km}$ na południe od Qumran i z leżącego $10 \mathrm{~km} \mathrm{w}$ kierunku południowo-zachodnim Chirbet Mird. (Hirkania) ${ }^{2}$ ) oraz $z$ innych miejsc, których znalazcy dokumentów nie chcą ujawnić. ${ }^{3}$ )

Dokumenty znalezione w grotach Pustyni Judzkiej w ciągu ostatnich dziesięciu lat można podzielić na kilka grup, które obejmować będą:

1. teksty hebrajskie, aramajskie i greckie ksiąg kanonicznych Starego Testamentu;

2. teksty hebrajskie i aramajskie ksiąg kanonicznych, znanych dotąd tylko z przekładu greckiego;

3. fragmenty greckich i syro-palestyńskich przekładów ksiąg hebrajskich Starego Testamentu;

1) por. F. M. Cross, Archaeological News and Views, Biblical Archaeologist, 18 (1955) $79 \mathrm{n}$.

$\left.{ }^{2}\right)$ por. R. de Vaux, Les grottes de Murabba'at et leurs documents, Revue Biblique $62(1953) 245 \mathrm{nn}$; A. Vincent, Les manuscrits hebreux du Désert de Juda, Paris 1955, $65 \mathrm{n}$.

${ }^{3}$ ) por. O. Eissfeldt, Einleitung in das Alte Testament, Tübingen 2. 1956, 789 n. 
4. teksty hebrajskie, aramajskie i greckie apokryfów starotestamentowych;

5. teksty hebrajskie i aramajskie apokryfów znanych dotąd tylko z przekładów;

6. nowe dotąd nieznane pisma apokryficzne.

Do pierwszej grupy należą przede wszystkim obydwa zwoje księgi Izajasza odkryte w pierwszej grocie w 1947 r. Pierwszy z nich oznaczony literą ,a” (DSIsa, 1 QIsa) zawiera tekst hebrajski całej ksiegi Izajasza. Drugi natomiast, oznaczony literą „b" (DSLsb, 1 QIsb) zawiera niekompletny tekst ksiegi ${ }^{4}$ ). Pierwszy zwój, obok Midraszu Habakuka, Księgi Reguły i niedawno rozwiniętego zwoju zawierającego aramajski midrasz do Księgi Rodzaju został początkowo nabyty przez schizmatycki klasztor syryjski św. Marka w Jerozolimie. Drugi natomiast razem z dwoma innymi zwojami zawierającymi ,Wojnę synów światłości z synami ciemności" i zbiór hymnów dziękczynnych stał się własnością Uniwersytetu Hebrajskiego w Jerozolimie.

W historii dokumentów z Qumran, a zwłaszcza w ich rozpoznaniu ważną rolę odegrał pierwszy zwój Izajasza. Na ten bowiem zwój zwrócił uwagę J. C. Trever, kiedy przybył do niego o. Butros Sowmy, ze schizmatyckiego klasztoru syryjskiego św. Marka, by z polecenia metropolity Mar Atanazjosa Jeszue Sámuela, prosić go o ocenę nabytych dokumentów. Nie zdając sobie sprawy z tego, co zwój zawiera, J. C. Trever przepisał ręcznie kilka wierszy z 51 kolumny i ze zdumieniem spostrzegł później, że jest to tekst Księgi Izajasza, który pismem swoim zbliża się do papirusu Nash'a najstarszego, dotąd znanego fragmentu tekstu hebrajskiego z II wieku przed Chr. ${ }^{5}$ ).

$\left.{ }^{4}\right)$ Początkowo zwoje znalezione W I grocie koło Qumran nazywano zwojami z nad Morza Martwego - Dead Sea Scrolls, kiedy jednak $w$ innych jeszcze miejscach nad Morzem Martwym znaleziono różne dokumenty, zaczęto zwoje i fragmenty oznaczać według miejsca znalezi Łnia, a więc Qumran, Murabba'at, Chirbet Mird. Groty zaznacza się koleinymi numerami, stąd np. 1 QIsa, 4 QIsc itp.

$\left.{ }^{5}\right)$ zob. jego art. The Discovery of the Scrools, w Biblical Archaeologist 11 (1948) 46-57; por. Mar Athanasius Y. Samuel, The Purchase of the Scrolls, tamże, 12 (1949) 26-31. 
Również prof. E. L. Sukenik (zm. 1953) na ten zwój zwrócił uwagę, kiedy na krótki czas otrzymał do wglądu nabyte przez klasztor św. Marka dokumenty. Odpisał on wówczas własnoręcznie ze zwoju tego kilka kolumn tekstu, w którym także rozpoznał tekst księgi Izajasza ${ }^{6}$ ). Po zidentyfikowaniu zawartości tego pierwszego zwoju, uczeni przystąpili do rozpoznawania treści pozostałych dokumentów, które jednak nie wszystkie zawierały teksty ksiąg biblijnych. Wszystkie te zwoje, znalezione w pierwszej grocie, po tranzakcji generała Yigael Yadina, syna prof. E. Sukenika, znajdują się obecnie w posiadaniu Uniwersytetu Hebrajskiego w Jerozolimie ${ }^{7}$ ).

\section{OPIS RĘKOPISÓW}

Najlepiej, z wszystkich dotąd znalezionych zwojów, zachował się pierwszy zwój ,a” zawierający cały tekst księgi Izajasza. Zwój ten składa się z 17 arkuszy pergaminu, dobrze wyprawionej oviczej skóry, zszytych lnianymi nićmi, których łączna długość wynosi $7 \mathrm{~m} 34 \mathrm{~cm}$, szerokość zaś 24,5 do $27 \mathrm{~cm}$. Tekst podzielony jest na 54 kolumny, każda zaś z nich zawiera 28 do 31 wierszy. Poszczególne arkusze były starannie poliniowane. Kopista nie stawiał liter na lini, ale pod linią. W przeciwieństwie do greckich uncjałów poszczególne wyrazy są oddzielone. Wolna przestrzeń dzieli także poszczególne paragrafy, a w ramach paragrafów poszczególne zdania, tak, że szeroko rozpowszechnione zdanie, iż w starożytności pisano w sposób ciągły „,scriptio continua" nie znajduje potwierdzenia w zwoju Izajasza ,a", 8 ).

Tekst napisany jest pismem kwadratowym. Pismo jest regularne wskazujące na biegłość kopisty, zbliżone do papirusu Nash'a. W kilkunastu miejscach zwój zawiera charakterystyczne znaki marginesowe, służące prawdopodobnie do celów litur-

$\left.{ }^{6}\right)$ por. E. L. Sukenik, The Dead Sea Scrolls of the Hebrew University, Jerusalem, 1955, $15 \mathrm{nn}$.

$\left.{ }^{7}\right)$ por. M. Burrows, The Dead Sea Scrolls, New York 1956, 37

$\left.{ }^{8}\right)$ por. G. Molin, Die Söhne des Lichtes, Wien-München 1954, 75. 
gicznych ${ }^{9}$ ). Niektóre $\mathrm{z}$ nich $\mathrm{J}$. Teicher niesłusznie uważa za znaki pochodzenia chrześcijańskiego ${ }^{10}$. Np. rozdział $36-39$ na początku i na końcu są oznaczone tymi znakami.

Rękopis wskazuje swoim wyglądem zewnętrznym, że używano go przez dłuższy czas. Pergamin jest bowiem dość wytarty $\mathrm{w}$ miejscu dotykania palcami, przybrudzony, postrzępiony, znać na nim ślady pęknięć, starannie pozszywanych na zewnętrznej stronie zwoju ${ }^{11}$ ).

Wokół zagadnienia wieku rękopisu wytworzyła się ożywiona i długa dyskusja, w wyniku której ustalono, że zwój ten pochodzi z II wieku przed Chr. W określeniu wieku zwoju oparto się grównie na kryteriach palecgraficznych. Wczesną datację dokumentu popierają także dane archeologiczne (miejsce znalezienia, ceramika z czasów rzymskich) i badania radioaktywne, którym poddano resztki płótna w jakie zawinięte były dokumenty $\left.{ }^{12}\right)$.

Tekst zwoju został opublikowany w r. $1950 \mathrm{w}$ pierwszym tomie wydania "The Dead Sea Scrolls of St. Mark's Monastery" staraniem M. Burrowsa przy pomocy J. C. Trevera i W. H. Brownlee, nakładem Amerykańskiej Szkoły Badań Orientalnych w New Haven ${ }^{13}$ ).

${ }^{9}$ ) por. J. Szeruda, Uwagi gramatyczne i tekstowo-krytyczne do nowoodkrytego rękopisu hebrajskiego Izajasza z Ain Fešha, Rocznik Orientalistyczny, 19 (1954) 146.

$\left.{ }^{10}\right)$ Material Evidence of the Christian Origin of the Dead Sea Scrolls, Journal of Jewish Studies, 3 (1952) 128-30; przeciw temu wypowiada się J. Sonne, 'The X-Sign in the Isaiah Scroll, Vetus Testamentum, 4 (1954) 90--94.

${ }^{11}$ ) por. J. T. Milik, Notte sui manoscritti di Ain Fešha, Biblica $31(1950) 78$.

12) por. W. F. Arbright, On the Date of the Scrolls from Ain Feskha and the Nash Papyrus, The Bulletin of American Schools of Oriental Research (BASOR), 115, 1949, 10-19; A. Bachaud, Radioactivité et âge des manuscrits du Désert de Juda, Nouvelle Revue Théologique, 72 (1950) 515-17. S. A. Birnbaum, How old are Cave Manuscripts. A Palaographical Discussion, Vet. Test., 1 (1951) 91-109.

13) The Dead Sea Scrolls of St. Mark's Monastery, vol. I, The Isaiah Manuscript and Habakkuk Commentary, New Haven 1950.

3 - Ruch Biblijny 
Drugi zwój „,b" zachował się w znacznie gorszym stanie. Zawiera on tekst księgi Izajasza od rozdziału 10 do końca, z tym jednak, że tekst ciągły zachował się dopiero od rozdziału 38, z poprzednich zaś rozdziałów (10-37) przechowały się tylko fragmenty. Był on tak zeschnięty i zniszczony, że trudno go było rozwinąć, a tekst udało się odczytać i sfotografować dopiero $\mathrm{z}$ pomocą promieni podczerwonych. $\mathrm{Z}$ całego zwoju zachowały się tylko cztery arkusze, które zawierają w dwunastu kolumnach tekst od rozdziału 38 do 65 . Eączna ich długość wynosi $141,5 \mathrm{~cm}$, szerokość natomiast 15 do $23 \mathrm{~cm}$. Z reszty zwoju, który przynajmniej był jeszcze raz tak długi, zachowało się tylko 11 fragmentów. Na najlepiej zachowanym, przedostatnim arkuszu skóry pozostały w poszczególnych kolumnach 34 wiersze. Zdaniem prof. E. Sukenika około 14 wierszy w dolnej części zwoju uległo zniszczeniu ${ }^{14}$ ). Rękopis ten mniej starannie napisany niż pierwszy, jest też od niego późniejszy. Pochodzi bowiem, jak wskazują dane paleograficzne z I wieku po Chr.

Opublikowaniem tego zwoju zajął się prof. E. L. Sukenik. Wydał on go razem $z$ dwoma innymi zwojami będącymi własnością Uniwersytetu Hebrajskiego w Jerozolimie, zawierającymí nieznany dotąd apokryf zatytułowany przez wydawcę „Wojna synów światłości z synami ciemności" (Milhamah, 1 QM) oraz zbiór hymnów dziękczynnych (Hodajoth, 1 QH) w r. 1954 w języku neohebrajskim ${ }^{15}$. W roku zaś 1955 ukazało się w Jerozolimie wydanie tych tekstów $w$ języku angielskim ${ }^{16}$ ).

\section{PORÓWNANIE Z TEKSTEM MASORECKIM}

Przed odkryciem dokumentów z Qumran najstarszymi zachowanymi rękopisami hebrajskimi były Kodeks Proroków z Kairu

14) por. E. L. Sukenik, The Dead Sea Scrolls of the Hebrew University, Jerusalem, 1955, 30.

$\left.{ }^{15}\right)$ Osar hammegilloth haggenuzoth szebidi hauniversitah haibrith, Jeruszalaim 5457 (1954). Wydanie to po smierci prof. E. L. Sukenika W r. 1953, przygotował do druku N. Avigad.

16) The Dead Sea Scrolls of the Hebrew University, Jerusalem 1955. 
(Codex Prophetarum Cairensis) z 893 r. oraz Petersburski Kodeks Proroków (Codex Prophetarum Petropolitanus) z 916 r. ${ }^{17}$ ). Przechowany $\mathrm{w}$ tych kodeksach tekst spółgłoskowy, ustalony przez Masoretów jest daleko starszy, sięga być może już drugiego wieku po Chr. ${ }^{18}$ ). Natomiast punktacja tego tekstu pochodzi z IX w. i jest wynikiem wieki trwających studiów i doświadczeń ${ }^{19}$ ). Powstawało stąd pytanie o ile wymowa proponowana przez Masoretów zgadza się ze starożytną wymową hebrajską, tym bardziej, że niemal tysiąc lat dzieliło ich od czasów, kiedy język hebrajski był mową żywą. Znalezienie dokumentów starszych o tysiąc lat niż dotychczas posiadane postawiło je w centrum zainteresowania uczonych. Tekstem Izajasza z Qumran zajęło się wielu semitologów.

Porównanie $\mathrm{z}$ tekstem masoreckim wykazuje, że tekst Izajasza z Qumran nie różni się w rozmiarach od tekstu przekazanego przez Masoretów. Nie brak w nim żadnej mowy, kolejność mów jest również taka sama. Tekst ten obejmuje także przypisywane innemu, a nawet dwom autorom rozdziały 40-66. Porównanie obydwu tekstów potwierdza niespodziewanie wymowę proponowaną przez Masoretów ${ }^{20}$ ) i wykazuje zasadniczą zgodność tekstu z Qumran z tekstem masoreckim, chociaż zgodność ta nie wyklucza pewnych odchylen.

Odchylenia tekstu z Qumran od tekstu masoreckiego dotyczą przeważnie ortografii, częściowo innej wokalizacji tekstu spółgłoskowego, niektóre zaś mają swe źródło w błędnym przepisaniu lub odczytaniu tekstu (dittografia 31, 6, haplografia $34,16$, powtarzanie i opuszczanie wyrazów 14,$18 ; 41,12)^{21}$ ).

$\mathrm{W}$ ortografii stwierdzić trzeba różnice $\mathrm{w}$ stosowaniu matres

${ }^{17}$ ) por. E. Würthwein, Der Text des Alten Testaments, Stuttgart. $1952,31 \mathrm{n}$.

${ }^{18}$ ) por. Würthwein, dz. cyt., 25.

$\left.{ }^{19}\right)$ E. Würthwein sądzi, że ,...heute vorliegende Punktation und Akzentuation das erst im Laufe des 9/10 Jahrhunderte erreichte Ergebnis jahrhundertelanger Studien, Versuche und Vorarbeiten ist', dz. cyt., $2 \overline{5}$.

$\left.{ }^{20}\right)$ por. tenże, dz. cyt., 26.

${ }^{21}$ ) por. J. T. Milik, art. cyt., 81. 
lectionis i w pisowni niektórych liter np. „mem” „lamed” ${ }^{22}$ ). $\mathrm{Na}$ końcu wyrazu często zamiast „he” pojawia się „lamed”. „Jod" i ,,waw" używane są promiscue, zamiennie. „Waw” często zastępuje ,szwa quiescens ${ }^{23}$ ). $\mathrm{Na}$ ogół w drugiej części manuskryptu ortografia jest przeprowadzona bardziej konsekwentnie, co zdaniem G. Molina zdaje się wskazywać, że była ona czymś nowym dla kopisty, który dopiero musiał się do niej przyzwyczaić. Swiadczyłoby to o tym, że język hebrajski był coraz mniej używany w życiu codziennym ${ }^{24}$ ).

Porównanie tekstów pozwala także stwierdzić pewne różnice gramatyczne, np. częstsze stosowanie przedimka $(1,2 ; 6,13)$. Zaimki wskazujące występują w starej formie i pełnej pisowni. Rzeczowniki mają w liczbie mnogiej końcówkę „iim”, a w sufiksie dzierżawczym rodz. męsk. mamy ,jod waw" zamiast „waw”. W odmianie czasowników spotyka się inną pisownię 2 os. 1. poj. r. żeńsk. Końcówka liczby mnogiej „waw” ma często „nun paragogicum”. Nie spotyka się kontrakcji w ,hifil” (3, 1; 57, 17). Czasowniki ,lamed-he” po ,waw consecutivum” mają formy pełne (bez apocope np. 5, 2. 4), a poza tym często zamieniają pisownię z czasownikami grupy ,lamed-alef”. W składni uderza swoiste stosowanie następstwa czasów (po imperfectum consecutivum jest perfectum consecutivum 36, 21). Orzeczenie przy podmiocie zbiorowym jest $w$ liczbie mnogiej $(54,3)$, natomiast w tekście masoreckim występuje w liczbie pojedynczej. Zauważyć można także aramaizmy np. końcówki liczby mnogiej ,iin” (23, 17). W słownictwie pojawiają się neologizmy lub formy pochodne wyrazów dawniej znanych $\left.2(, 20 ; 14,20 ; 11)^{25}\right)$.

Obok różnic w ortografii i gramatyce naliczono ok. 1500 różnic tekstowych ${ }^{26}$ ). Powodem tych różnic są opuszczenia i braki.

${ }^{22}$ ) por. M. Burrows, dz. cyt., $92 \mathrm{n}$.

${ }^{23}$ ) por. J. T. Milik, art. cyt., $204 \mathrm{n}$; J. Szeruda, art. cyt., 149 n.

${ }^{25}$ ) - pör. J. Szeruda, art. cyt., $148 \mathrm{n}$.

24) por. dz. cyt., 76 .

${ }^{26)}$ ) por. W. Baumgärtner, Die hebräischen und aramäischen Handschriften aus Palästina, Theologische Zeitschrift, 1951, 76. 
W kilkudziesięciu miejscach tekst Izajasza ,a" jest krótszy od tekstu masoreckiego np. 2, 3 brak 3 wyrazów potrzebnych ze względu na paralelizm, 52, 4 brak 6 wyrazów, których brak też w Septuagincie (LXX); między 34, 17 b a 35, 2 brak 31 wyrazów, które zostały później uzupełnione inną ręką i z innego tekstu. Są także w tekście z Qumran pewne dodatki. M. Burrows wylicza ich około $40^{27}$ ). Np. 53, 8 dodaje ,kare mu zadano”. Spotyka się również różnice $\mathrm{w}$ wyrazach wskutek zamiany liter wzgl. opuszczenia (49,7, ,którym gardza poganie”, TM „gardzacy poganami”, 50,2 ,usycha” jak w LXX, TM „gnije”, 53,3 ,i gardziliśmy nim", TM ,i wzgardzony"; 53,11 jak w LXX dodaje ,,Światło”), niedość starannego przepisywania, przestawiania wyrazów lub grup wyrazów $(23,9 ; 37,1.7 ; 43,3 ; 63,9)$.

Zasadniczych różnic jednak, takich które by dotyczyły tekstu jest niewiele ${ }^{28}$ ) np. 42,4 ,a jego nauke odziedzicza wyspy" TM ma lekcję lepszą,na jego nauke wyspy oczekujo"; 42,1 TM „stuga mój... posiałem go... aby zanióst narodom prawo" 1 QIsa dodaje „swoje prawo”, jak LXX dodaje w 53,11 ,światło", które to słowo nadaje większą jasność tekstowi; 52, 14 TM ,tak było zeszpecone oblicze jego, a wyglad jego nie byا godny człowieka” 1 QIsa ma „ja przez namaszczenie dam mu wyglad przewyższający czlowieka" a więc coś przeciwnego. D. Barthélemy sądzi i zapewne nie bez słuszności, że w TM widać wpływy niechęci do chrześcijańskiej interpretacji tego tekstu, oraz zaznacza, że w ten sposób chciano zmniejszyć jego znaczenie mesjańskie.

\section{PORÓWNANIE Z PRZEKLADAMi STAROŻYTNYMI}

Porównanie tekstu Izajasza ,a" z Qumran, który jest szczególnie ważny dlatego, że przechował się w tym rękopisie cały tekst księgi biblijnej, i bliższe zestawienie go z tekstem maso-

${ }^{27}$ ) Variant Readings in the Isaiah Manuscript, BASOR, 111, 1948, $18 \mathrm{n}$.

${ }^{28}$ ) por. D. Barthélemy, Le grand rouleau d'Isaïe, Revue Biblique; 59 (1950) 530-49. 
reckim wykazuje pewne, jak widzieliśmy nieznaczne różnice nie pozwalające jednak na utożsamienie obydwóch tekstów. Zmiany w tekście, ich ilość i charakter wskazują, że powstały one w okresie, gdy nie było jeszcze jednego miarodajnego tekstu. Można przypuszczać, że tekst Izajasza „a" reprezentuje jedną $\mathrm{z}$ rozpowszechnionych $\mathrm{w}$ owych czasach recenzję tekstu, różną od masoreckiego i później przezeń wypartą.

Fakt, że tekst z Qumran różni się od tekstu masoreckiego zrodził jednocześnie pytanie, jaki jest stosunek tekstu Izajasza „a" z Qumran do Septuaginty. Porównanie obydwu tekstów pod tym względem wykazało, że tylko w dwudziestu miejscach Izajasz z Qumran zgadza się z Septuagintą, tam gdzie ona odchyla się od tekstu masoreckiego ${ }^{29}$ ). Co więcej doprowadziło uczonych do stwierdzenia, że mimo małej odległości czasowej dzielącej tekst ,a” z Qumran od LXX, różni się on od niej daleko więcej niż od tekstu masoreckiego. Dalsze dociekania wykazały, że tekst Izajasza „a” więcej różni się od Septuaginty, niż od późniejszego od niej syryjskiego przekładu Peszitty czy aramajskich Targumów ${ }^{30}$ ). Tekst ten bynajmniej nie okazał się ogniwem pośrednim pomiędzy LXX a tekstem masoreckim i nie przemawia na korzyść monistycznego ujęcia tekstu, ale popiera stanowisko plụralistycznego ujęcia tekstu wyrażające się w przekonaniu, że w starożytności istniało kilka recenzji tekstu hebrajskiego, które w ciągu wieków zostały wyparte przez tekst masorecki ${ }^{31}$ ).

\section{PORÓWNANIE 1 QIsb $Z$ TEKSTEM MASORECKIM, 1 QIsa I PRZEKLADAMI}

Zajmowaliśmy się dotąd porównaniem tekstu Izajasza „a" tak z tekstem masoreckim jak i z przekładami i zauważyliśmy, że nie pokrywa się $\mathrm{z}$ żadnym $\mathrm{z}$ nich. Podobne porównanie tek-

$\left.{ }^{29}\right)$ por. J. T. Milik, art. cyt., 86.

s6) por. M. Gottstein, Die Jesaja-Rolle im Lichte von Peschitta und Targum, Biblica 35 (1954) 52.

$\left.{ }^{51}\right)$ por. M. Gottstein, art. cyt., $51-56$. 
stu Izajasza „b” z Qumran z tekstem masoreckim wykazuje, że zbliża on się bardziej do niego niż 1 QIsa. Jeśli bowiem ten ostatni różni się w stosunkowo dość wielu miejscach od tekstu masoreckiego, to drugi zwój Izajasza wykazuje daleko mniej wariantów tekstowych. Drobne zmiany dotyczą głównie pisowni - scriptio plena i scriptio defectiva - która zresztą nie jest zupełnie ustalona nawet $\mathrm{w}$ kodeksach Masory ${ }^{32}$ ). Nie tylko pod względem ortografii, ale i pod względem gramatyki zbliża się Izajasz „b” bardziej do tekstu masoreckiego. J. T. Milik pisze nawet, że ,odnosi się wrażenie, iż ma się przed soba tekst masorecki" ${ }^{33}$ ). Niemniej jednak i tego tekstu $z$ masoreckim utożsamiać nie można, bo różnice choć nieznaczne, jednak istnieją. Spotykamy w 1 QIsb pisownię defektywną w formach imiennych i słownych od pierwiastków, „waw” i ,jod”. Końcowe „waw" nie ulega zamianie na „ôt”, w końcówce żeńskiej liczby mnogiej. W imiesłowie ,qal praesens" widoczna jest skłonność do użycia „waw” jako długiej samogłoski. Poza tym tekst Izajasza „,b” zgadza się z Masorą. W różnicach tekstowych zanotować należy opuszczenia $(16,10 ; 37,10$, gdzie tekst masorecki ma 20 liter więcej), homoioteleuton (38, 12-13), który był powodem opuszczenia całego wiersza i dodatki $(49,7 ; 55,11)$ zgodne jednak z 1 QIsa ${ }^{34}$ ). Poza tym E. L. Sukeniik zaznacza 16 miejsc, w których 1 QIsb zgadza się z Septuagintą przeciw TM i 1 QIsa ${ }^{35}$ ).Porównanie więc wykazuje, że drugi teǩkst Izajasza z Qumran, choć bardzo zbliża się do tekstu masoreckiego, to jednak nie może być z nim utożsamiony, podobnie jak nie identyfikuje się on $\mathrm{z}$ tekstem hebrajskim, który służył za podstawę tłumaczenia Septuaginty. Różni się on także od tekstu

${ }^{32}$ ) por. E. L. Sukenik, dz. cyt., 30.

${ }^{33}$ ) Il rottolo frammentario di Isaia, Biblica 31 (1950) 530-49; Sukenik pisze na ten temat: „The scroll is quite close to the Masoretic text of the Book of Isaiah in its readings and in its spellings", dz. cyt. 30 .

${ }^{34}$ ) por. P. W. Skehan, Tte Text of Isaias of Qumran, The Catholic Biblical Quarterly, 17 (1955) 160.

$\left.{ }^{35}\right)$ dz. cyt., 31-34. Pełną listę wariantów daje S. Loewinger, The Variants of DSIsb, Vetus Test., 4 (1954) 155-63. 
pierwszego zwoju Izajasza ,a” z Qumran. Wszystko to przemawia za tym, że w czasie kiedy pisano drugi zwój Izajasza z Qumran, nie obowiązywał jeden jednolity tekst, jak później masorecki ${ }^{36}$ ). Wskazuje to również na to, że tekst ten reprezentuje jeszcze jedną odmianę tekstu, rozpowszechnioną przed ujednoliceniem tekstu spółgłoskowego ${ }^{37}$ ).

\section{ZNACZENIE RĘKOPISÓW KSIĘGI IZAJASZA Z QUMRAN}

W grotach $\mathrm{w}$ pobliżu ruin Qumran znaleziono w latach następnych inne jeszcze fragmenty Księgi Izajasza. W samej tylko grocie czwartej znaleziono ich dwanaście ${ }^{38}$ ). Fragmenty te bynajmniej nie pochodzą z jednej ręki i nie reprezentują tego samego tekstu. $\mathrm{Z}$ wszystkich znalezionych dotąd tekstów Księgi Izajasza najstarszym pod względem paleografii jest pierwszy, kompletny zwój Izajasza znaleziony w pierwszej grocie ${ }^{39}$ ). Toteż na tekst tego zwoju zwraca się szczególną uwagę.

Znalezione dotąd zwoje i fragmenty, zachodzące między nimi różnice, utwierdzają uczonych w przekonaniu, że w starożytności istniało kilka recenzji tekstu hebrajskiego Starego Testamentu. Istnienie tych recenzji pozwoli wytłumaczyć rozbieżności jakie widzimy pomiędzy tekstem z Qumran a tekstem masoreckim i starymi przekładami. Zdaniem W. F. Albrighta premasorecki tekst z Qumran jest przedstawicielem recenzji babilońskiej, Septuaginta natomiast reprezentuje recenzję aleksandryjską ${ }^{40}$ ). Jednakże badanie tych tekstów wskazuje też na to, że już w czasach przedchrześcijańskich istniała tendencja do zastąpienia szeregu rozpowszechnionych tekstów jednym tekstem jednolitym ${ }^{41}$ ).

${ }^{36}$ ) por. P. W. Skehan, The Text of Isaias at Qumran, The Catholic Biblical Quarterly, 17 (1955) 160.

${ }^{37}$ ) por. M. Burrows, The Dead Sea Scrolls, 314.

${ }^{38}$ ) por. P. W. Skehan, art. cyt., 158.

${ }^{39}$ ) por. P. W. Skehan, art. cyt., 162.

$\left.{ }^{40}\right)$ New Light on early Recensions of the Hebrew Bible, BASOR, 140, $1955,27-35$.

${ }^{41}$ ) por. O. Eissfeldt, dz. cyt., 836. 
Biorąc pod uwagę odległość niemal dziesięciu wieków dzielącą tekst z Qumran od najstarszych rękopisów tekstu masoreckiego spodziewać by się można daleko większych rozbieżności. Tymczasem poza widocznymi różnicami w ortografii i gramatyce między obydwoma tekstami panuje zasadnicza zgodność. Tekst Izajasza z Qumran w zadziwiający sposób, mimo takiej odległości czasowej, potwierdza wierność tradycyjnego tekstu Masoretów ${ }^{42}$ ). Widać też z tego, że większe zmiany w przekazie zostały dokonane już przed erą chrześcijańską, czyli na dwa, trzy wieki przedtem, nim Masoreci rozpoczęli oficjalnie swoje dzieło. Zdaniem M. Burrowsa główne znaczenie rękopisów z Qumran polega na tym, że potwierdzają one wierność tradycji masoreckiej ${ }^{43}$ ).

Warianty tekstu z Qumran nie wiele wnoszą i nie są zbyt ważne dla krytyki tekstu, choć nie spotyka się ich w znanych dotąd rękopisach hebrajskich. Są one daleko ważniejsze dla historii języka i gramatyki historycznej. Znane dotąd ujednolicone przekazy tekstu hebrajskiego nie dawały wielkiego wglądu w rozwój hebrajskich form gramatycznych. Teksty zaś z Qumran dostarczają pewnej sumy form gramatycznych odbiegających od form tekstu masoreckiego. Pozwala to głębiej wniknąc w rozwój języka i to w okresie dotąd zupełnie w historii języka nieznanym ${ }^{44}$ ). Dlatego i z tyh racji dokumenty z Qumran posiadają tak wielkie znaczenie.

Lublin,

Ks. WITOLD TYLOCH

${ }^{42}$ ) por. E. Würthwein, dz. cyt., 26.

${ }^{43}$ ) The Dead Sea Scrolls, 303 n; por. P. W. Skehan, árt. cyt., 162.

${ }^{44}$ ) por. R. Meyer, Probleme der hebräischen Grammatik, Zeitschrift fuir die alttestamentliche Wissenschaft, 53 (1951) $221 \mathrm{n}$. 